\title{
Seasonal and intraspecific variation of frost tolerance in leaves of three Canarian laurel forest tree species
}

\author{
Águeda Ma GonZÁleZ-RodríguEZ*, Mª Soledad JimÉnEZ, Domingo MorALES \\ Dpto. de Biología Vegetal, Universidad de La Laguna, 38207 La Laguna, Tenerife, Spain
}

(Received 20 July 2004; accepted 3 March 2005)

\begin{abstract}
The effect of freezing temperatures was studied in leaves of three tree species growing in the laurel forest of the Canary Islands, relictic vegetation of Tertiary Mediterranean flora. The decrease in photochemical capacity of PSII (Fv/Fm) was compared with visual assessment to determine the degree of frost damage $24 \mathrm{~h}$ after treatment. The study was carried out in sun and shade leaves, and in two different seasons, to obtain information about the intraspecific and seasonal variability of frost resistance of these three species. Our results showed that the studied species are sensitive to freezing temperatures, Laurus azorica being the most resistant species, undergoing damage at $-10^{\circ} \mathrm{C}$, while Persea indica and Myrica faya were damaged at $-6^{\circ} \mathrm{C}$ and $-4^{\circ} \mathrm{C}$, respectively. In the warm season, sun leaves were less resistant to freezing temperatures than in the cold season and these leaves showed lower resistance than shade ones. The frost resistance shown by these species was lower than that of most Mediterranean woody species. However, the existence of other Mediterranean woody plants, with similar sensitivity to freezing temperatures, indicates that low temperatures were probably not the main cause in the past of their present confinement.
\end{abstract}

chlorophyll fluorescence / Laurus azorica / Persea indica / Myrica faya / visual damage

Résumé - Variation saisonnière et intraspécifique de la tolérance à la gelée des feuilles de trois espèces arborescentes de la forêt de laurier des îles Canaries. L'effet du gel a été étudié chez des feuilles de trois espèces d'arbres de la forêt de laurier des îles Canaries, végétation relique de la flore méditerranéenne du tertiaire. La diminution de la capacité photochimique de PSII (Fv/Fm) a été comparée à l'évaluation visuelle pour déterminer le degré de dommages de la gelée $24 \mathrm{~h}$ après le traitement. L'étude a été effectuée pour les feuilles de lumière et d'ombre, et à deux saisons différentes, pour obtenir des informations sur la variabilité intraspécifique et saisonnière de la résistance à la gelée de ces trois espèces. Nos résultats ont prouvé que les espèces étudiées sont sensibles au gel et Laurus azorica est l'espèce la plus résistante qui subira des dommages à $-10^{\circ} \mathrm{C}$, cependant Persea indica et Myrica faya ont été endommagées à $-6^{\circ} \mathrm{C}$ et à $-4^{\circ} \mathrm{C}$, respectivement. Pendant la saison chaude, les feuilles de lumière étaient moins résistantes au gel que pendant la saison froide et ces feuilles ont montré des résistances inférieures à celles des feuilles d'ombre. La résistance à la gelée des ces espèces a été plus faible que celle des espèces ligneuses méditerranéennes. Cependant, l'existence d'autres plantes ligneuses méditerranéennes, avec une sensibilité semblable aux températures de gel, indique que les basses températures n'étaient probablement pas la cause principale dans le passé de leur confinement actuel.

fluorescence de la chlorophylle / Laurus azorica / Persea indica / Myrica faya / dommages visuels

\section{INTRODUCTION}

The Canarian laurel forest is a luxuriant vegetation with a diverse structure of trees, shrubs, herbs, climbers, ferns, mosses, lichens, and fungi. About 20 tree species belonging to different families are present in this evergreen forest, the majority of which are Canarian Macaronesian endemics. Trees generally have broad leaves, always green and glossy, making up a dense canopy with different anatomical and physiological leaf characteristics [27]. These forests have the typical appearance of a cloud forest [16] and are mainly restricted to the most humid section of the northern (windward) slope in middle elevations where there is an almost permanent cloud belt. They are relicts of a now virtually extinct Tertiary Mediterranean flora that occupied southern Europe and North Africa about 20 million years ago $[10,37]$ and disappeared during the Quaternary glaciations. Knowledge of eventual low temperature effect on their physiology is of considerable interest since this could be one of the causes of their present confinement to the Islands where the climate is milder than that of the Mediterranean Basin.

It is known that exposure of leaves to temperatures below a critical level results in irreversible damage to the photosynthetic apparatus [22]. The measurement of chlorophyll fluorescence has long been used as a sensitive, reliable, and rapid method to determine the effect of environmental stresses, including chilling and freezing stress $[4,6,8,32,33]$. Another method, which has also been used to assess tissue damage due

\footnotetext{
*Corresponding author: aglerod@ull.es
} 
to freezing, is the direct observation of visible damage or mortality [5, 7, 21, 23].

The aim of this study is to assess the effect of freezing temperatures on the leaves of three laurel forest tree species growing in the Canary Islands in order to understand whether the effect of freezing temperatures in the past could be the cause of their present confinement. Chlorophyll fluorescence as an indicator of damage to the photosynthetic apparatus and visual assessment of damage after freezing were used to evaluate the effect of low temperatures. Furthermore, the possibility that damage produced by freezing temperatures showed an intraspecific variation between leaves exposed in the upper crown (sun leaves) and in the lower and inner parts (shade leaves) of the dense canopy of this forest was studied. Lastly, although this forest presents almost stable microenvironmental conditions, the eventual seasonal variation of frost tolerance was tested.

\section{MATERIALS AND METHODS}

\subsection{Plant material}

Leaves inserted in the upper and outer crown (sun leaves) and in the lower and inner parts of the canopy (shade leaves) of Laurus azorica (Seub.) Franco, Persea indica (L.) C. K. Spreng. and Myrica faya Aiton were collected from dominant, about 37-year old, 18-m high individuals of these tree species (two trees per species) in an experimental plot of laurel forest situated at an altitude of $820 \mathrm{~m}$ a.s.l. on the Agua García Mountain, Tenerife (further details of the plot in [27-29]). The climate at the site is humid Mediterranean with a 20-year mean annual temperature of $14{ }^{\circ} \mathrm{C}$ (absolute maximum and minimum of $39^{\circ} \mathrm{C}$ and $0.2^{\circ} \mathrm{C}$, respectively), mean relative humidity of $80 \%$, and mean annual precipitation of $733 \mathrm{~mm}$ per year [11].

Previous climatic studies showed two different seasons at the study site: one dry and warm season from June to September and another wet and colder season from October to May [9]. To assess the possible seasonal variation in the degree of frost tolerance, leaves were taken during these two different seasons. Sampling months were March in the cold season and September in the warm season.

Mean temperature in March (cold season) was about $10^{\circ} \mathrm{C}$, with a mean maximum and minimum temperature of $14{ }^{\circ} \mathrm{C}$ and $6.5^{\circ} \mathrm{C}$, respectively. In September (warm season), the mean temperature was about $17{ }^{\circ} \mathrm{C}$ and mean maximum and minimum temperatures were $21^{\circ} \mathrm{C}$ and $14^{\circ} \mathrm{C}$, respectively.

A scaffolding tower in the experimental plot provided access to the top (sun leaves, $18 \mathrm{~m}$ above ground) and to the lower part (shade leaves, $12 \mathrm{~m}$ above ground) of the canopy where whole mature leaves were detached and immediately transferred to the laboratory. Leaves were kept overnight in closed chamber with water-saturated air before exposing them for $30 \mathrm{~min}$ in plastic bags in a dark water bath (heat control: DT Hetotherm, cold control: Hetofrig CB IIe, Heto) to different temperature treatments with steps $2^{\circ} \mathrm{C}$ from $0{ }^{\circ} \mathrm{C}$ to $-14^{\circ} \mathrm{C}$. The effects of treatments were monitored $24 \mathrm{~h}$ after the leaf samples were left in a closed dark chamber with water-saturated air at room temperature, by chlorophyll fluorescence and by observing visible symptoms. Six leaves were tested for each temperature treatment and both visual assessment and measurements of Fv/Fm were performed in the same leaves.

\subsection{Measurement of chlorophyll fluorescence}

Room temperature chlorophyll fluorescence of dark adapted leaves was measured by a time-resolving portable fluorometer (Plant Effi-

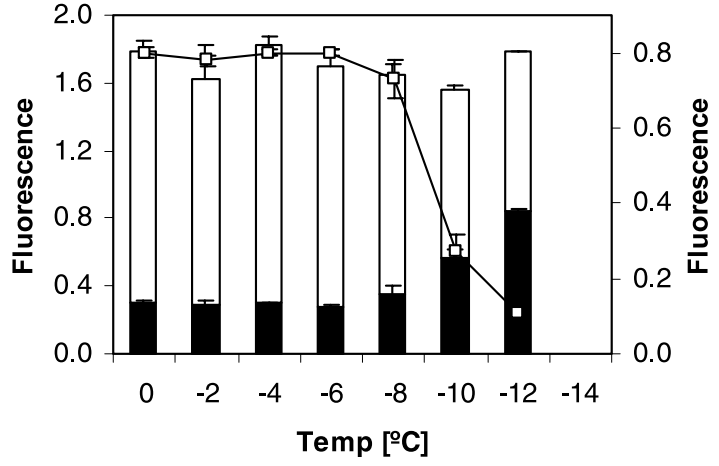

Figure 1. Example of variation of initial (Fo, white bar), maximal fluorescence (Fm, dark bar) and $\mathrm{Fv} / \mathrm{Fm}$ ratio (square) in response to freezing temperatures in sun leaves of Laurus azorica in the cold season. Data represent the mean of six measurements with their standard deviations.

ciency Analyser, PEA, Hansatech, UK). Exposure for 2 min to an actinic light with a flux of $3000 \mu \mathrm{mol} \mathrm{m} \mathrm{m}^{-2} \mathrm{~s}^{-1}$ and a peak wavelength of $690 \mathrm{~nm}$ resulted in the instantaneous measurement of different fluorescence parameters, from which the photochemical capacity of PSII $(\mathrm{Fv} / \mathrm{Fm})$ was determined.

$\mathrm{Fv} / \mathrm{Fm}$ values measured $24 \mathrm{~h}$ after temperature treatment were statistically analysed using ANOVA with main effects and two-way interactions. Post-Hoc analyses were realised by Tukey's test using $P=0.05$ as the critical level of significance. All statistical analyses were performed using the SPSS (SPSS 11.5 Inc. 2003) package.

\subsection{Visual assessment of frost damage}

The extent of necrotic patches on the leaves was estimated after full development of the symptoms. Threshold values for injury were obtained by visual rating [21], $\mathrm{LT}_{\mathrm{i}}$ being the incipient killing temperature, i.e., the temperature at which injuries first appear, and $\mathrm{LT}_{50}$ the temperature at which $50 \%$ of leaf area is necrotic.

\section{RESULTS}

\subsection{Chlorophyll fluorescence: Photochemical capacity of PSII}

Values of fluorescence parameters in the studied species showed a deviation from the normal ones after exposure to low temperatures. In particular, a decrease in the Fm values and an increase in Fo values were correlated with a decrease in $\mathrm{Fv} / \mathrm{Fm}$ (Fig. 1). Values of this last parameter in response to freezing temperatures for each studied species are shown in Figure 2.

Statistical analysis of $\mathrm{Fv} / \mathrm{Fm}$ showed significant differences $(P<0.001)$ among the three studied species. An individual statistical study was subsequently carried out for each species to determine the effect of the freezing temperature, type of leaf and season (Tabs. I-III).

Regardless of leaf type and season, a marked difference was observed in freezing tolerance among species, $L$. azorica being the most resistant, followed by $P$. indica and $M$. faya. In particular, 
L. azorica
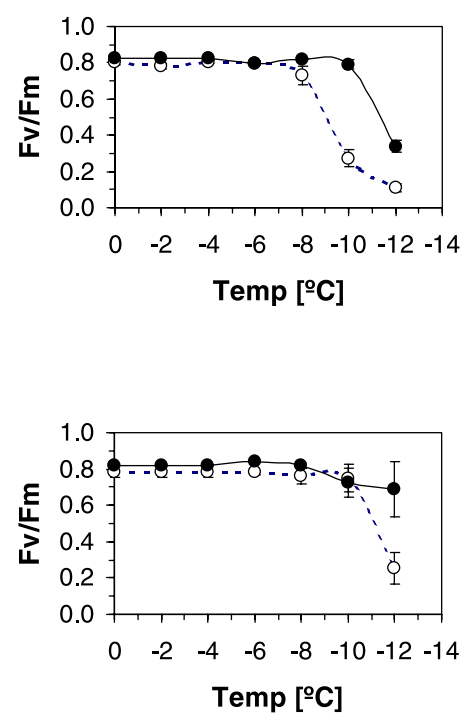

P. indica Warm season

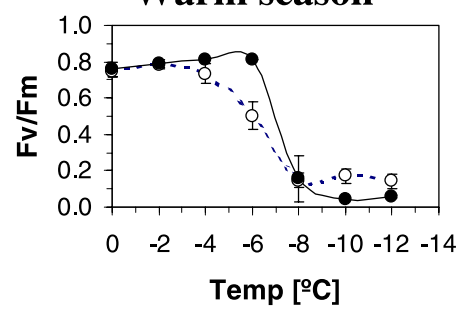

Cold season

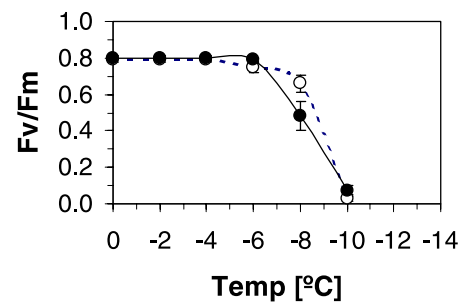

M. faya
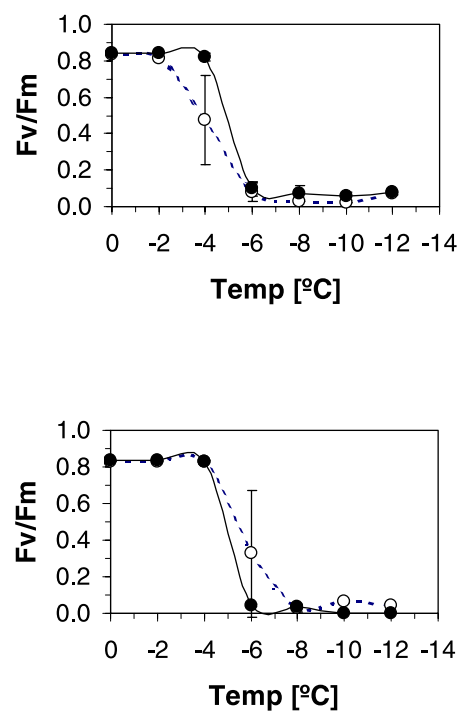

Figure 2. Response to freezing temperatures by upper crown leaves (sun leaves, white circle) and inner crown leaves (shade leaves, dark circle) in the warm and cold seasons, assessed by the Fv/Fm chlorophyll fluorescence parameter in the tree species Laurus azorica, Persea indica and Myrica faya. Each point represents the mean of six measurements with their standard deviations.

Table I. Average values and standard deviations of the Fv/Fm parameter in response to freezing temperatures in sun and shade leaves of Laurus azorica during warm and cold seasons.

\begin{tabular}{lccccc}
\hline \multirow{2}{*}{$\begin{array}{c}\text { Temperature } \\
\left({ }^{\circ} \mathrm{C}\right)\end{array}$} & \multicolumn{3}{c}{ S. azorica } \\
\cline { 2 - 3 } \cline { 6 - 6 } \cline { 5 - 6 } & \multicolumn{2}{c}{ Warm Season Cold Season } & & \multicolumn{2}{c}{ Sharm Season Cold leaf } \\
\hline 0 & $0.84 \pm 0.01^{\mathrm{a}}$ & $0.82 \pm 0.01^{\mathrm{a}}$ & & $0.84 \pm 0.00^{\mathrm{a}}$ & $0.83 \pm 0.01^{\mathrm{a}}$ \\
-2 & $0.82 \pm 0.02^{\mathrm{a}}$ & $0.79 \pm 0.09^{\mathrm{a}}$ & & $0.84 \pm 0.00^{\mathrm{a}}$ & $0.84 \pm 0.01^{\mathrm{a}}$ \\
-4 & $0.83 \pm 0.02^{\mathrm{a}}$ & $0.82 \pm 0.01^{\mathrm{a}}$ & & $0.84 \pm 0.01^{\mathrm{a}}$ & $0.83 \pm 0.01^{\mathrm{a}}$ \\
-6 & $0.84 \pm 0.01^{\mathrm{a}}$ & $0.79 \pm 0.09^{\mathrm{a}}$ & & $0.81 \pm 0.02^{\mathrm{a}}$ & $0.84 \pm 0.01^{\mathrm{a}}$ \\
-8 & $0.77 \pm 0.06^{\mathrm{a}}$ & $0.83 \pm 0.03^{\mathrm{a}}$ & & $0.84 \pm 0.01^{\mathrm{a}}$ & $0.82 \pm 0.02^{\mathrm{a}}$ \\
-10 & $0.31 \pm 0.06^{\mathrm{b}, \mathrm{o}}$ & $0.81 \pm 0.05^{\mathrm{a}, *}$ & $0.82 \pm 0.03^{\mathrm{a}}$ & $0.80 \pm 0.05^{\mathrm{a}}$ \\
-12 & $0.14 \pm 0.0^{\mathrm{c}, \mathrm{o}}$ & $0.30 \pm 0.11^{\mathrm{b}, \mathrm{o}}$ & $0.37 \pm 0.03^{\mathrm{b}}$ & $0.69 \pm 0.19^{\mathrm{a}, *}$ \\
\hline
\end{tabular}

Letters denote significant differences among temperature treatments $(P<0.05)$. Asterisks indicate significant differences between warm and cold season in the same type of leaf $(P<0.05)$. Circles indicate significant differences between sun and shade leaves in the same season $(P<0.05)$.

L. azorica showed damage at $-10^{\circ} \mathrm{C}$, while $P$. indica and $M$. faya were damaged at $-6^{\circ} \mathrm{C}$ and $-4^{\circ} \mathrm{C}$, respectively.

Sun leaves were more sensitive to freezing temperatures than shade ones during the warm season (damage was sustained $2{ }^{\circ} \mathrm{C}$ lower), but no differences were observed in this regard during the cold season. Moreover, in all three species leaves were more sensitive to freezing temperatures in the warm season
Table II. Average values and standard deviations of the Fv/Fm parameter in response to freezing temperatures in sun and shade leaves of Persea indica during warm and cold seasons.

\begin{tabular}{|c|c|c|c|c|}
\hline \multirow{3}{*}{$\begin{array}{c}\text { Temperature } \\
\left({ }^{\circ} \mathrm{C}\right)\end{array}$} & \multicolumn{4}{|c|}{ P. indica } \\
\hline & \multicolumn{2}{|c|}{ Sun leaf } & \multicolumn{2}{|c|}{ Shade leaf } \\
\hline & Warm Season & Cold Season & Warm Season & Cold Season \\
\hline 0 & $0.79 \pm 0.04^{\mathrm{a}}$ & $0.85 \pm 0.01^{\mathrm{a}}$ & $0.80 \pm 0.05^{\mathrm{a}}$ & $0.80 \pm 0.04^{\mathrm{a}}$ \\
\hline-2 & $0.82 \pm 0.02^{\mathrm{a}}$ & $0.85 \pm 0.00^{\mathrm{a}}$ & $0.84 \pm 0.03^{\mathrm{a}}$ & $0.83 \pm 0.02^{\mathrm{a}}$ \\
\hline-4 & $0.78 \pm 0.07^{\mathrm{a}}$ & $0.85 \pm 0.01^{\mathrm{a}}$ & $0.86 \pm 0.01^{\mathrm{a}}$ & $0.82 \pm 0.02^{\mathrm{a}}$ \\
\hline-6 & $0.55 \pm 0.09^{\mathrm{b}, \mathrm{o}}$ & $0.81 \pm 0.03^{\mathrm{a}, *}$ & $0.86 \pm 0.01^{\mathrm{a}}$ & $0.83 \pm 0.02^{\mathrm{a}}$ \\
\hline-8 & $0.19 \pm 0.05^{\mathrm{c}}$ & $0.72 \pm 0.06^{\mathrm{b}, *, \mathrm{o}}$ & $0.25 \pm 0.14^{b}$ & $0.51 \pm 0.09^{\mathrm{b}, *}$ \\
\hline-10 & $0.21 \pm 0.05^{\mathrm{c}, \mathrm{o}}$ & $0.09 \pm 0.02^{\mathrm{c}, *}$ & $0.09 \pm 0.00^{b}$ & $0.10 \pm 0.03^{c}$ \\
\hline-12 & $0.18 \pm 0.05^{\mathrm{c}}$ & $0.09 \pm 0.02^{\mathrm{c}, *}$ & $0.10 \pm 0.01^{b}$ & $0.10 \pm 0.03^{\mathrm{c}}$ \\
\hline
\end{tabular}

Letters denote significant differences among temperature treatments $(P<0.05)$. Asterisks indicate significant differences between warm and cold season in the same type of leaf $(P<0.05)$. Circles indicate significant differences between sun and shade leaves in the same season $(P<0.05)$.

with respect to the cold season. In $L$. azorica the damage temperature $\mathrm{LT}_{\mathrm{i}}$, was shown to be at $-10^{\circ} \mathrm{C}$ and $-12^{\circ} \mathrm{C}$ in sun and shade leaves, respectively, in the warm season. No seasonal differences were found in shade leaves. A similar tendency was observed when damage was studied in P. indica and M. faya, which showed the same behaviour as L. azorica, with differences of $2{ }^{\circ} \mathrm{C}$ in sun leaves in the warm season. 
Table III. Average values and standard deviations of the Fv/Fm parameter in response to freezing temperatures in sun and shade leaves of Myrica faya during warm and cold seasons.

\begin{tabular}{|c|c|c|c|}
\hline \multirow{3}{*}{$\begin{array}{c}\text { Temperature } \\
\left({ }^{\circ} \mathrm{C}\right)\end{array}$} & \multicolumn{3}{|c|}{ M. faya } \\
\hline & \multicolumn{2}{|c|}{ Sun leaf } & Shade leaf \\
\hline & Warm Season & Cold Season & Warm Season Cold Season \\
\hline 0 & $0.85 \pm 0.00^{\mathrm{a}}$ & $0.86 \pm 0.00^{\mathrm{a}}$ & $0.84 \pm 0.02^{\mathrm{a}} \quad 0.86 \pm 0.01^{\mathrm{a}}$ \\
\hline-2 & $0.84 \pm 0.01^{\mathrm{a}}$ & $0.86 \pm 0.02^{\mathrm{a}}$ & $0.84 \pm 0.01^{\mathrm{a}} \quad 0.83 \pm 0.01^{\mathrm{a}}$ \\
\hline-4 & $0.50 \pm 0.22^{\mathrm{b}, \mathrm{o}}$ & $0.86 \pm 0.01^{\mathrm{a}, *}$ & $0.82 \pm 0.03^{\mathrm{a}} \quad 0.86 \pm 0.01^{\mathrm{a}}$ \\
\hline-6 & $0.10 \pm 0.06^{\mathrm{c}}$ & $0.36 \pm 0.18^{\mathrm{b}, *, \mathrm{o}}$ & $0.10 \pm 0.05^{\mathrm{b}} \quad 0.07 \pm 0.01^{\mathrm{b}}$ \\
\hline-8 & $0.05 \pm 0.00^{\mathrm{c}}$ & $0.07 \pm 0.01^{\mathrm{b}, *, \mathrm{o}}$ & $0.08 \pm 0.04^{b} \quad 0.06 \pm 0.00^{c}$ \\
\hline-10 & $0.04 \pm 0.00^{c}$ & $0.10 \pm 0.01^{\mathrm{b}, *, \mathrm{o}}$ & $0.06 \pm 0.02^{\mathrm{b}} \quad 0.03 \pm 0.00^{\mathrm{d}}$ \\
\hline-12 & $0.09 \pm 0.01^{\mathrm{c}}$ & $0.08 \pm 0.00^{\mathrm{b}, \mathrm{o}}$ & $0.08 \pm 0.01^{\mathrm{b}} 0.03 \pm 0.00^{\mathrm{d}, *}$ \\
\hline
\end{tabular}

Letters denote significant differences among temperature treatments $(P<0.05)$. Asterisks indicate significant differences between warm and cold season in the same type of leaf $(P<0.05)$. Circles indicate significant differences between sun and shade leaves in the same season $(P<0.05)$.

Table IV. Visual assessment of frost damage in upper crown leaves (sun leaves) and inner crown leaves (shade leaves) during warm and cold seasons in Laurus azorica, Persea indica and Myrica faya. Temperature of incipient $\left(\mathrm{LT}_{\mathrm{i}}\right)$ and irreversible $\left(\mathrm{LT}_{50}\right)$ damage are shown. $\mathrm{LT}_{\mathrm{i}}$ is the incipient killing temperature, i.e. the temperature at which injuries first appear; and $\mathrm{LT}_{50}$, the temperature at which $50 \%$ of leaf area is necrotic.

\begin{tabular}{|c|c|c|c|c|}
\hline Species & Type of leaf & Season & $\mathrm{LT}_{\mathrm{i}}$ & $\mathrm{LT}_{50}$ \\
\hline \multirow{4}{*}{ L. azorica } & Sun & Warm & -6 & -8 \\
\hline & & Cold & -8 & -10 \\
\hline & Shade & Warm & -6 & -10 \\
\hline & & Cold & -8 & -12 \\
\hline \multirow{4}{*}{$P$. indica } & Sun & Warm & -4 & -6 \\
\hline & & Cold & -7 & -8 \\
\hline & Shade & Warm & -7 & -7 \\
\hline & & Cold & -6 & -8 \\
\hline \multirow{4}{*}{ M. faya } & Sun & Warm & -3 & -4 \\
\hline & & Cold & -5 & -5 \\
\hline & Shade & Warm & -4 & -5 \\
\hline & & Cold & -5 & -5 \\
\hline
\end{tabular}

\subsection{Visual damage}

Visually assessed damage induced by freezing temperatures developed gradually. The first symptoms were a blushing of the main and secondary veins. Then small brown necrotic patches appeared on the surface of the leaves which, with the decrease in temperature, covered the whole surface.

In general, damage caused by freezing temperatures was detected by visual assessment before being measured by the chlorophyll fluorescence method. The visually estimated damage level showed a similar tendency to those afforded by flu- orescence techniques, L. azorica being the most resistant species, and sun leaves and warm season the most sensitive factors in regard to freezing temperatures (Tab. IV).

\section{DISCUSSION}

Freezing temperatures affected $\mathrm{Fv} / \mathrm{Fm}$ ratios in the species studied. The decrease in $\mathrm{Fv} / \mathrm{Fm}$ ratio after freezing indicates a change of photosystem II reaction centres from functional state to down-regulated or nonfunctional ones [18, 19, 34, 38]. This represents a disturbance of photosynthetic performance since photochemical capacity $(\mathrm{Fv} / \mathrm{Fm})$ is known to be correlated with quantum yield of photosystem II [2, 3].

The visual assessment was a sensitive method for detecting damage caused by freezing temperatures in the three studied species. Damage was first detected by this method before fluorescence measurements were affected. This is due to the fact that the initial symptoms of damage were a blushing of the main and secondary veins and the damage was detected by chlorophyll fluorescence measurements only when the surface of the leaves was affected. Although this result may seem irrelevant, this behaviour is not common to all species. For example, in many species, visually estimated freezing damage correlated well with a decrease in Fv/Fm [1, 5, 7, 25, 31]. In contrast, the damage in Pinus canariensis was never observed with this assessment [33].

From our results we can conclude that the photosynthetic apparatus of $L$. azorica, $P$. indica and $M$. faya are sensitive to freezing temperatures. In general, L. azorica was the most resistant species, showing damage at $-10^{\circ} \mathrm{C}$, followed by $P$. indica and $M$. faya that were damaged at $-6{ }^{\circ} \mathrm{C}$ and $-4{ }^{\circ} \mathrm{C}$, respectively. Therefore L. azorica is at the lower limit of resistance in the range given by Sakai and Larcher [36] for most Mediterranean woody plants such as Laurus nobilis, other Mediterranean sclerophylls and Mediterranean conifers.

In the case of $P$. indica, this result agrees with that obtained in two species of the same genus [20,23]. M. faya is a more freezing temperature-sensitive species than its congeners, $M$. rubra, a species from subtropical regions, and $M$. californica, a species from regions with warm-temperate climates, which are damaged at $-10^{\circ} \mathrm{C}$ and $-15^{\circ} \mathrm{C}$, respectively [36].

In general, sun leaves were less resistant to freezing temperatures than shade ones mainly in the warm season and this effect was more pronounced in L. azorica. Because the high degree of light adaptation of leaves is usually associated with a higher stress tolerance [24], our results might seem contradictory. However, the light adaptation capacity of plants is genetically fixed and it should be borne in mind that the studied trees are adapted to very wet and shady habitats, where the laurel forest is distributed [16]. Nevertheless the leaves which develop in the upper canopy have to cope with strong light conditions on clear days $[13,30]$, therefore only species such as those studied, that can modify their morphology and physiology to adapt to the changing conditions along the canopy, are able to grow in this dense forest [27]. The fact that the photosynthetic apparatus of sun leaves begins to be affected at much higher temperatures than shade leaves indicates that the above-mentioned changes undergone in the sun leaves, including chlorophyll contents and antenna size, could bring about a greater susceptibility to damage 
in antenna pigments, although they would be better adapted to endure higher levels of light. This explanation was also given to justify similar results obtained in comparable experiments carried out in sun and shade leaves of the same species but in relation to dehydration [17], where shade leaves were again more resistant.

No seasonal variation in the degree of frost tolerance was observed in shade leaves. Only the sun leaves showed slight seasonal variations of frost tolerance and this could be due to the conditions experienced by these leaves in the open canopy. It should be borne in mind that this forest presents stable microenvironmental conditions without significant temporal variations and an acquired freezing resistance with time does not seem plausible.

The issue to be resolved is why these trees, relicts of a now virtually extinct Tertiary Mediterranean flora that occupied southern Europe and North Africa, disappeared from that region, being presently relegated to the Atlantic islands where the weather conditions are milder. There are two main constraints in the Mediterranean habitat for these plants, cold during the winter and drought during the summer. The thermal crisis of the Pleistocene, with cool periods, probably 5 to $10^{\circ} \mathrm{C}$ colder than at present, may have forced selection of plants living in the Mediterranean regions for low-temperature resistance or for survival in frost-free zones [36]. The three studied species are freezing-sensitive plants throughout the year and less frost-resistant than the majority of the Mediterranean woody species [36], and they seem to have evolved according to the latter option. Nevertheless there are plants with a similar range of temperature resistance to the studied tree species that are actually widespread in the Mediterranean region, for example Ceratonia siliqua and Nerium oleander, for which $\mathrm{LT}_{50}$ values of $-6^{\circ} \mathrm{C}$ and $8^{\circ} \mathrm{C}$ have been reported [36]. Therefore, it is not clear whether this may be the only cause of their confinement to the Macaronesian region. These tree species are not very prone to endure arid conditions [26] and field studies on stomatal behaviour and transpiration [12, 14, 15, 39] showed their weak ability for physiological regulation of water loss. Considering that drought stress proves to be the climatic factor essentially responsible for the restriction of productivity and survival of woody evergreen plants in Mediterranean-type regions [35], we think that this could be one of the main causes of their confinement to the islands, where there are zones in which the summer drought is mitigated by a persistent cloud belt, precisely the zones where these trees are living at present. However, studies focused to find out freezing-induced embolism should be done, since this might also be a physiological factor affecting past and present distribution of Mediterranean versus relict species.

Acknowledgements: We wish to thank Juliane Peters, Gilberto Cruz and María del Carmen González Silgo for their kind assistance during the experiments. Agueda $\mathrm{M}^{\mathrm{a}}$ González-Rodríguez would also like to express her gratitude to the Consejería de Educación, Cultura y Deportes of the Canarian Government for a grant which has made this work possible. This work has been financed by the DGICYT project No. PB94-0580 (Spanish Government) and the Viceconsejería de Educación (Canarian Government).

\section{REFERENCES}

[1] Adams G.T., Perkins T.D., Assessing cold tolerance in Picea using chlorophyll fluorescence, Env. Exp. Bot. 33 (1993) 377-382.

[2] Adams W.W., Demmig-Adams B., Winter K., Schreiber U., The ratio of variable to maximum chlorophyll fluorescence from photosystem II, measured in leaves at ambient temperature and at $77 \mathrm{~K}$, as an indicator of the photon yield of photosynthesis, Planta 180 (1990) 166-174.

[3] Björkman O., Demmig B., Photon yield of $\mathrm{O}_{2}$ evolution and chlorophyll fluorescence characteristics at $77 \mathrm{~K}$ among vascular plants of diverse origins, Planta 170 (1987) 489-504.

[4] Boorse G.C., Bosma T.L., Meyer A.-C., Ewers F.W., Davis D., Comparative methods of estimating freezing temperatures and freezing injury in leaves of chaparral shrubs, Int. J. Plant Sci. 159 (1998) 513-521.

[5] Boorse G.C., Ewers F.W., Davis S.D., Response of chaparral shrubs to below-freezing temperatures: acclimation, ecotypes, seedlings vs. adults, Am. J. Bot. 85 (1998) 1224-1230.

[6] Brüggemann W., Low-temperature limitations of photosynthesis in three tropical Vigna species: a chlorophyll fluorescence study, Photosynth. Res. 34 (1992) 301-310.

[7] Clement J.M.A.M., van Hasselt P.R., Chlorophyll fluorescence as a parameter for frost hardiness in winter wheat. A comparison with other hardiness parameters, Phyton 36 (1996) 29-41.

[8] Fernández M., Royo A., Gil L., Pardos J.A., Effects of temperatura on growth and stress hardening development of phytotron-grown seedlings of Aleppo pine (Pinus halepensis Mill.), Ann. For. Sci. 60 (2003) 277-284.

[9] García Gallo A., Wildpret de la Torre W., Estudio florístico y fitosociológico del bosque de Madre del Agua en Agua García (Tenerife), in: Homenaje al Profesor Doctor Telesforo Bravo, Universidad de La Laguna, Secretariado de Publicaciones, 1990, pp. 307347.

[10] González Henríquez M.N., Rodrigo Pérez J.D., Suárez Rodríguez C., Flora y vegetación del archipiélago canario, Edirca, Las Palmas de Gran Canaria, 1986.

[11] González-Rodríguez A.M., Caracterización fotosintética de árboles de la laurisilva canaria, Universidad de La Laguna, Tenerife, Spain, 1998.

[12] González-Rodríguez A.M., Morales D., Jiménez M.S., Gas exchange characteristics of a Canarian laurel forest tree species (Laurus azorica) in relation to environmental conditions and leaf canopy position, Tree Physiol. 21 (2001) 1039-1045.

[13] González-Rodríguez A.M., Tausz M., Wonisch A., Jiménez M.S., Grill D., Morales D., The significance of xanthophylls and tocopherols in photo-oxidative stress and photoprotection of three Canarian laurel forest tree species on a high radiation day, J. Plant Physiol. 158 (2001) 1547-1554.

[14] González-Rodríguez A.M., Morales D., Jiménez M.S., Leaf gas exchange characteristics in relation to leaf canopy position of Myrica faya in its native environment (Tenerife, Canary Islands), Plant Biol. 4 (2002) 576-583.

[15] González-Rodríguez A.M., Morales D., Jiménez M.S., Leaf gas exchange characteristics of a Canarian laurel forest tree species Persea indica (L.) K. Spreng. under natural conditions, J. Plant Physiol. 159 (2002) 695-704.

[16] Hollermann P., Microenvironmental studies in the laurel forest of the Canary Islands, Mt. Res. Dev. 1 (1981) 193-207.

[17] Jiménez M.S., González-Rodríguez A.M., Morales D., Effect of dehydration on the photosynthetic apparatus of sun and shade leaves of laurel forest trees, Z. Naturforsch. C54 (1999) 704-710.

[18] Krause G.H., Photoinhibition and photosynthesis. An evaluation of damaging and protective mechanisms, Physiol. Plant. 74 (1988) $566-574$.

[19] Krause G.H., Grafflage S., Rumich-Bayer S., Somersalo S., Effects of freezing on plant mesophyll cells, in: Long S.F., Woodward F.I. (Eds.), Plants and Temperature, Comp. Biol. Ltd., Cambridge, 1988, pp. 311-327. 
[20] Larcher W., La posizione delle piante sempreverdi mediterranee nella evoluzione della resistenza al freddo. Atti dell' Istituto Veneto di Scienze, Lettere ed Arti 138 (1980) 103-111.

[21] Larcher W., Vitalitätsbestimmung, in: Kreeb K.H., Fischer G. (Eds.), Methoden zur Pflanzenökologie und Bioindikation, 2. Aufl., Jena, 1990, pp. 251-265.

[22] Larcher W., Physiological Plant Ecology, 4th ed., Springer-Verlag, Berlin-Heidelberg-New York, 2003.

[23] Larcher W., Wagner J., Neuner G., Méndez M., Jiménez M.S., Morales D., Thermal limits of photosynthetic function and viability of leaves of Persea indica and Persea americana, Acta Oecol. 12 (1991) 529-541.

[24] Lichtenthaler H.K., Vegetation Stress: an introduction to the stress concept in plants, J. Plant Physiol. 148 (1996) 4-14.

[25] Lindgren K., Hällgren J.E., Cold acclimation of Pinus contorta and Pinus sylvestris assessed by chlorophyll fluorescence, Tree Physiol. 13 (1993) 97-106.

[26] Lösch R., Water relations of Canarian laurel forest trees, in: Borguetti M, Grace J., Raschi A. (Eds.), Water transport in plants under climatic stress, Cambridge Univ. Press, Cambridge, 1993, pp. 243-246.

[27] Morales D., González-Rodríguez A.M., Cermák J., Jiménez M.S., Laurel forests in Tenerife, Canary Islands: The vertical profiles of leaf characteristics, Phyton 36 (1996) 251-263.

[28] Morales D., Jiménez M.S., González-Rodríguez A.M., Cermák J., Laurel forests in Tenerife, Canary Islands. I. The site, stand structure and stand leaf area distribution, Trees 11 (1996) 34-40.

[29] Morales D., Jiménez M.S., González-Rodríguez A.M., Cermák J., Laurel forests in Tenerife, Canary Islands. II. Leaf distribution in individual tree, Trees 11 (1996) 41-46.
[30] Morales D., González-Rodríguez A.M., Tausz M., Grill D., Jiménez M.S., Oxygen stress and pigment composition in Canarian laurel forest trees, Phyton Ann. Rei. Bot. A. 37 (1997) 181-186.

[31] Neuner G., Buchner O., Assessment of foliar frost damage: a comparison of in vivo chlorophyll fluorescence with other viability tests, J. Appl. Bot. 73 (1999) 50-54.

[32] Öquist G., Hurry V.M., Huner N.P.A., The temperature dependence of the redox state of $\mathrm{Q}_{A}$ and susceptibility of photosynthesis to photoinhibition, Plant Physiol. Bioch. 31 (1993) 683-691.

[33] Peters J., Jiménez M.S., Morales D., Effect of extreme temperatures on quantum yield of fluorescence and membrane leakage of the Canarian endemic pine (Pinus canariensis), Z. Naturforsch. 54 (1999) 681-687.

[34] Powles S.B., Photoinhibition of photosynthesis induced by visible light, Annu. Rev. Plant Physiol. 35 (1984) 15-44.

[35] Roy J., Aronson J., di Castri F., Time scales of biological responses to water constraints. The case of Mediterranean biota, SPB Academic Publ., Amsterdam, 1995.

[36] Sakai A., Larcher W., Frost survival of plants. Responses and Adaptation to freezing stress, Ecological Studies, Vol. 62, Springer-Verlag, 1987.

[37] Santos A., Evergreen forests in the Macaronesian region, Council of Europe, Strasbourg, 1990.

[38] Somersalo S., Krause G.H., Effects of freezing and subsequent light stress on photosynthesis of spinach leaves, Plant Physiol. Bioch. 28 (1990) 467-475.

[39] Zohlen A., González-Rodríguez A.M., Jiménez M.S., Lösch R., Morales, D., Transpiración y regulación estomática en árboles de la laurisilva canaria medidos en primavera, Vieraea 24 (1995) 91104. 